osobowością w dziejach dydaktyki i oddziaływujacego na nauczanie we wszystkich ówcźesnych szkołach.

Trzecia grupa to rozprawy zwiazane z problematyka morską. Mamy więc tutaj teksty dotyczące nauczania wiedzy zwiazanej z morzem oraz rozwoju nauk morskich $w$ okresie od XVI do XVIII wieku w Gdańsku.

Wreszcie czwarta grupa to prace dotyczace dziejów instytucji edukacyjnych istniejących w Gdańsku w okresie staropolskim. Oczywiście na plan pierwszy dziejów oświaty w dawnym Gdańsku wysuwa się działajace tam od 1558 roku Gimnazjum Akademickie. Stąd w omawianym tomie nie mogło zabraknąc tekstów dotyczących działalności luterańskich gimnazjów w Prusach Królewskich. Wymienieni wyżej uczeni byli w większości profesorami Gdańskiego Gimnazjum Akademickiego, tak więc prace o ich działalności i twórczości są jednocześnie związane z problematyka gimnazjum.

Wśród szerokich zainteresowań L. Mokrzeckiego ważną rolę odgrywaja dzieje nauczania konkretnych przedmiotów. O nauczaniu tych zwiazanych $\mathrm{z}$ morzem już wspomniano, ale to tylko fragment zainteresowań autora omawianego tomu. Znajdujemy w nim także rozważania na temat wychowania muzycznego w gimnazjach akademickich, nauczania historii nie tylko $w$ dawnym Gdańsku, ale także w całej Rzeczypospolitej na tle europejskim oraz uwagi o wychowaniu i wiedzy wojskowej w oświacie I Rzeczypospolitej. Wreszcie omawia autor (wspólnie w Kazimierzem Puchowskim) programy szkolnictwa staropolskiego w XVI i XVII wieku.

Jako ostatni zamieszczono tekst o kształtowaniu się obowiązku szkolnego w Polsce od XVI do końca XX stulecia. Tom kończy bibliografia prac L. Mokrzeckiego oraz indeks nazwisk.

Omawiany tom $\mathrm{z}$ pewnością zainteresuje wszystkich zajmujących się okresem staropolskim, dziejami oświaty tego okresu, problematyka morska, historiografia staropolska, czy po prostu dziejami Gdańska.

Dorota Żotadź-Strzelczyk

\title{
Pedagogika Nowego Wychowania w Polsce u schyłku XIX i w pierwszej połowie XX wieku, pod red. Andrzeja Meissnera i Czesława Majorka, „Galicja i jej dziedzictwo” Tom 14, Wyd. WSP w Rzeszowie, Rzeszów 2000, ss. 445
}

Pedagogika Nowego Wychowania w Polsce u schylku XIX $i$ w pierwszej potowie XX wieku to kolejny już 14 tom studiów publikowany $w$ ramach serii wydawniczej Galicja i jej dziedzictwo. Zawiera on materiały $\mathrm{z}$ Międzynarodowej Konferencji zorganizowanej przez Zakład Historii Wychowania Instytutu Pedagogiki Wyższej Szkoły Pedagogicznej w Rzeszowie w dniach $12-14$ października 1998 r., poświęconej właśnie pedagogice „Nowego Wychowania”. Uczestniczyli w niej historycy wychowania $z$ Polski, Słowacji i Ukrainy.

Konferencji przyświecały dwa zasadnicze cele. Po pierwsze podjęto próbę zaprezentowania głównych idei pedagogiki "Nowgo Wychowania" na ziemiach polskich pod koniec XIX w. i w I po- łowie wieku XX. Po drugie, podjęto również próbę ukazania roli idei pedagogicznych "Nowego Wychowania" w przebudowie polskiej szkoly w omawianych okresach historycznych. Pojawiła się też potrzeba oceny tego kierunku pedagogicznego zarówno w odniesieniu do wypracowanych teorii, jak i praktycznych rozwiazań. Jest rzecza interesujaca, czy „Nowe Wychowanie" przeszlo już do historii, czy też nadal żyje we wspólczesnej pedagogice? Czy twórcze niegdyś rozwiazania i projekty reform szkolnych moga być dziś wykorzystane $w$ procesie reformowania polskiego szkolnictwa?

Omawiany tom składa się z czterech części odpowiadajacych czterem sekcjom problemowym. 
Część pierwsza zatytułowano Nowe Wychowanie: historyczne źródta $i$ wspótczesne odniesienia. Znalazło się tu sześć opracowań autorów polskich, slowackich i ukraińskich, którzy podjęli próbę ukazania genezy „Nowego Wychowania” we własnych krajach i roli, jaka ten nurt odegrał w kształtowaniu teorii i praktyki pedagogicznej.

Tę część otwiera publikacja Jana Szmyda dotycząca postmodernistycznej myśli pedagogicznej, ukazująca analogie, zbieżności i podobieństwa tradycji „Nowego wychowania” z pedagogika postmodernizmu.

Następne opracowanie stanowi referat Jana Sryndy. Jest to szkic polemiczny przedstawiający m.in. kontrowersje wokól interpretacji terminu „Nowe Wychowanie" oraz chronologicznych granic tego nurtu w Polsce. Wyjaśnia przyczyny powstania tego nowego prądu w wychowaniu i kształceniu na ziemiach polskich.

Słowaka, Igora Kominareca, porusza problematyka wychowania narodowego Słowacji w kontekście historycznym od połowy XIX do $\mathrm{XX}$ wieku włącznie. Ukazuje wpływ różnych czynników, m.in. społeczno-politycznych, na rozwój szkolnictwa i wychowania narodowego.

Ciekawe przemyślenia zawiera opracowanie Bogdana Stuparyka dotyczace idei wychowania narodowego w ukraińskiej myśli pedagogicznej okresu międzywojennego.

Część pierwszą zamykają rozprawy: B. Śliwerskiego - ukazująca ostatnie przemiany oświatowe w Polsce oraz Edmunda Lubasza - prezentująca ,pedagogikę reformy na Słowacji w okresie międzywojennym".

Część druga niniejszego tomu, pt. Ludzie Nowego Wychowania, poświęcona jest wybitnym przedstawicielom tegoż nurtu. Znajdujemy tu m.in. sylwetki Henryka Rowida, Stanisława Markiewicza, Jerzego Ostrowskiego, Jana Kuchty, Jacka Woronieckiego i Janusza Korczaka. Ponadto zostały też ukazane poglądy pedagogów słowackich i ukraińskich. Autorzy artykułów podjęli próbę nowego spojrzenia na poglądy wymienionych reprezentantów „Nowego Wychowania”, a także wydobyli na światło dzienne mniej znane aspekty ich działalności oświatowej. Część ta składa się z dziesięciu referatów (Andrzeja Meissnera, Danuty Koźmin, Josefa Psenaka, Viery
Zbirkovej, Anny Batiuk, Józefa Krasuskiego, Katarzyny Kalinowskiej, Jana Hellwiga, Eugenii Lesiak-Laska).

Część trzecia tomu zatytułowana jest Nowe Wychowanie na tamach czasopism pedagogicznych $i$ oświatowych. Autorzy poszczególnych opracowań Kazimierz Szmyd, Halina Raczek, Barbara Luczyńska, Iwona Michalska, Violetta Rodek, Tadeusz Jałmużna, Stanisław Majewski poddali analizie takie czasopisma, jak: „Muzeum”, „Szkoła”, „Ruch Pedagogiczny”, „Teatr w Szkole”, „Praca Szkolna”, „Przyjaciel Szkoły" oraz uczniowskie pisma szkół łódzkich. Literatura tych opracowań przekonuje, że polskie czasopisma pedagogiczne żywo reagowały na hasła $\mathrm{i}$ idee pomagające przebudowie systemu edukacji w okresie „nowego wychowania XIX wieku". Niniejsza część zawiera siedem referatów.

Najbardziej wartościowa a jednocześnie najobszerniejsza jest część czwarta, zatytułowana Innowacyjna dziatalność szkót, instytucji $i$ organizacji $w$ duchu Nowego Wychowania. Zawiera ona przykłady różnych rozwiązań innowacyjnych i eksperymentów pedagogicznych oraz programów oświatowych wypracowanych przez środowiska nauczycielskie, organizacje młodzieżowe, czy też partie polityczne.

W tej części swoje wystąpienia zawarli Wiesław Jamrożek, Jerzy Potoczny, Irina Krulak, Krzysztof Jakubiak, Edyta Wolter, Iwona Wendeńska, Elżbieta Magiera, Marta Uberman, Adam Krzanowski, Edyta Głowacka, Grzegorz Michalski.

Częsść czwartą kończy artykuł Kazimierza Rędzińskiego.

Całość pracy zamyka przemówienic Andrzeja Meissnera wygłoszone $\mathrm{z}$ okazji odsłonięcia tablicy poświęconej H. Rawidowi. Zamieszczono też sprawozdania $\mathrm{z}$ obrad poszczególnych sekcji oraz ciekawe podsumowanie całości konferencji dokonane przez prof. Czesława Majorka.

Andrzej Spadlo 